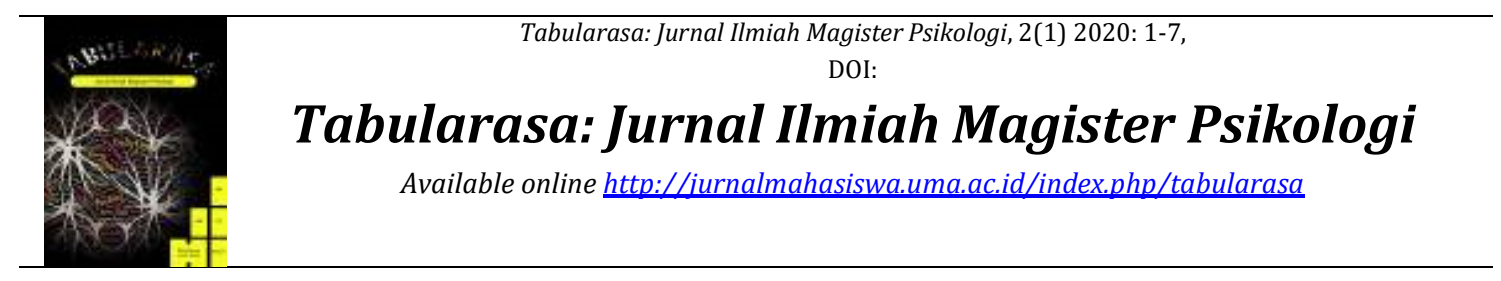

\title{
Hubungan Self Efficacy dan Dukungan Keluarga dengan Kecemasan Siswa pada Pelajaran Matematika Sekolah Menegah Atas Negeri 2 Sinabang
}

\section{Self Efficacy Relationship And Family Support With Students 'Anxiety In Mathematics High School 2 Sinabang}

\author{
Mariatun*, Abdul Munir \& Cut Metia
}

Program Studi Magister Psikologi , Pascasarjana, Universitas Medan Area Email: mariatunpsi@gmail.com

\begin{abstract}
Abstrak
Penelitian ini bertujuan untuk mengetahui (1) Hubungan self efficacy dan dukungan keluarga dengan kecemasan siswa pada pelajaran matematika; (2) Hubungan self efficacy dengan kecemasan siswa pada pelajaran matematka; (3) Hubungan dukungan keluarga dengan kecemasan siswa pada pelajaran matematika. Penelitian ini menggunakan pendekatan kuantitatif dengan menggunakan instrumen yaitu skala kecemasan siswa pada pelajaran matematika, skala self efficacy dan skala dukungan keluarga. Teknik analisis data yang digunakan adalah analisis regresi ganda dan analisis korelasi parsial. Adapun hasil penelitian dapat disimpulkan ada hubungan yang signifikan antara self efficacy dan dukungan keluarga dengan kecemasan siswa pada pelajaran matematika yang ditunjukkan oleh koefisien $F=12.239 ; \mathrm{R}=.548$ dengan $\mathrm{p}=0.000(\mathrm{p}<0,01)$. Selain itu, hasil penelitian juga menunjukkan ada hubungan self efficacy dengan kecemasan siswa pada pelajaran matematika yang ditunjukkan oleh koefisien rx1-y $=-0.543$ dengan $\mathrm{p}<0.01$, dan ada hubungan dukungan keluarga dengan kecemasan siswa pada pelajaran matematika yang ditunjukkan oleh koefisien rx2-y $=-0.257$ dengan $\mathrm{p}<0.01$ dimana self efficacy dan dukungan keluarga memberikan sumbangan terhadap kecemasan siswa pada pelajaran matematika sebesar 30\%; ternyata self efficacy memberikan konstribusi sebesar 29.5\% dan dukungan keluarga sebesar $6.6 \%$.
\end{abstract}

Kata Kunci : Kecemasan Siswa, Pelajaran Matematika, Self efficacy, Dukungan keluarga

\begin{abstract}
The objective of this research was to find out (1) the correlation between the students' self efficacy, their family support, and their math anxiety, (2) the correlation between the students' self efficacy and their math anxiety, and (3) the correlation between the students' family support and their math anxiety. A math anxiety scale, a self-efficacy scale, and a family support scale were used as the instruments in this quantitative research. The collected data were then analyzed by using multiple regression and partial correlation analyses. The results indicated that the students' self efficacy and their family support were in a significant correlation with those students' math anxiety. It was showed by the coefficient $F=12.239 ; R=.548$ with $p=0.000(p<0.01)$. Moreover, it was also found that there was a correlation between the students' self efficacy and their math anxiety with coefficient $r \times 1-y=-0.543$ with $p<0.01$. In addition, the students' family support was correlated to their math anxiety with coefficient $r \times 2-y=-0.257$ with $p<0.01$. The students' self efficacy and their family support gave as much as 30\% of the influence in which $29.5 \%$ of it was from the self efficacy variable while $6.6 \%$ of it was from the family support variable.
\end{abstract}

Keywords : Students' Math Anxiety, Self Efficacy, Family Support

How to Cite: Mariatun, Munir, A, \& Metia, C. (2020). Hubungan Self Efficacy dan Dukungan Keluarga dengan Kecemasan Siswa pada Pelajaran Matematika SMA Negeri 2 Sinabang. Tabularasa: Jurnal Ilmiah Magister Psikologi, 2(1) 2020: 1-7

*E-mail: mariatunanggi@gmail.com

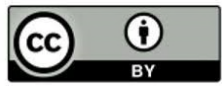

This work is licensed under a Creative Commons Attribution 4.0 


\section{PENDAHULUAN}

Setiap individu pernah mengalami kecemasan, karena kecemasan adalah bagian dari kehidupan. Ziglar (dalam Metia,2016) yang meneliti tentang kecemasan menyatakan bahwa sebanyak $40 \%$ manusia cenderung merasa cemas terhadap hal-hal yang belum terjadi, 30\%, merasa cemas terhadap hal-hal yang telah terjadi, dan 30\% merasa cemas pada hal-hal yang tidak mendasar seperti masa depan, kesehatan dan lainnya.

Kecemasan terhadap pelajran matematika sering dapat dilihat pada siswa Sekolah Lanjutan Tingkat Pertama dan sekolah Lanjutan Tingkat Atas. Hurlock (1997) berpendapat bahwa kecemasan merupakan sebuah ungkapan perasaan individu terhadap suatu situasi yang dapat diekspresikan melalui beberapa cara, yaitu dengan cara yang mudah dikenali seperti kekhawatiran dan menjadi mudah marah. Pada hal-hal tertentu, misalnya kecemasan kecemasan pada bidang matematika. Kecemasan terlihat dari kekhawatiran individu. Selanjutnya Zbornik (dalam Rifai, 2014) menyatakan bahwa kecemasan matematika sebagai gejala spesifik yang tersusun dari komponen terhadap tes meliputi kekhawatiran merupakan aspek kognitif dari kecemasan, dan aspek emosional serta sebuah aspek unik yaitu kecemasan yang berhubungan dengan bilangan. Lebih lanjut Rosadah (dalam Kurniati dan siswono, 2014) mengemukakan bahwa kecemasan matematika dianggap salah satu faktor penghambat belajar yang mengganggu kinerja fungsi-fungsi kognitif. Selanjutnya Scarpello (dalam Suminta, 2014) berpendapat bahwa siswa yang mengalami kecemasan matematika kurang memiliki percaya diri untuk mengerjakan matematika dan cenderung menghindari mata pelajaran matematika atau berhitung, serta membatasi pilihan karir siswa.

Hasil observasi dan interview yang dilakukan peneliti pada beberapa pihak sekolah seperti wakil kepala Sekolah bagian Pengajaran, guru BK dan siswa SMA Negeri 2 Sinabang yang dilakukan pada tanggal 27 sampai 28 Februari 2017 menyampaikan bahwa siswa-siswi SMA Negeri 2 Sinabang berjumlah 286 siswa. Dari laporan dan dokumen catatan guru BK bahwa siswa-siswa yang mengalami kecemasan pada pelajaran matematika sebanyak 70\% dari jumlah keseluruhan siswa-siswi. Prestasi belajar matematika mereka mayoritas juga kurang. Menurut Wakil Kepala Sekolah bagian pengajaran menyampaikan bahwa banyak yang menjadi penyebab menurunnya prestasi belajar anak. Salah satunya yang paling besar terjadi di SMA Negeri 2 Sinabang adalah kecemasan siswa pada pelajaran matematika Hal ini terlihat dari nilai yang diperoleh, pada saat belajar mereka selalu keluar masuk kelas, kurang perhatian pada pelajaran, mengantuk/tidur dalam kelas dan senang mengganggu teman. Pendapat ini di dukung juga oleh hasil observasi langsung yang dilakukan peneliti pada tanggal 5 Oktober 2016, dimana pada saat proses belajar mengajar (PBM) di dalam kelas beberapa siswa terlihat kurang memperhatikan saat guru menyampaikan materi pelajaran, berbicara dalam kelas, tidur, mengantuk, serta menggunakan HP pada saat sedang belajar, sedangkan pada saat pergantian jam pelajaran, siswa keluar masuk kelas. Namun tidak semua siswa SMA Negeri 2 Sinabang mengalami kecemasan pada pelajaran matematika.

Dari catatan dan dokumen BK diperoleh informasi bahwa siswa-siswi ini memiliki keyakinan yang kuat bahwa bila mereka bersungguh-sungguh belajar keras dan tidak 
mudah menyerah mereka akan menerima hasil yang baik dan sesuai dengan yang diharapkan. Meskipun mereka memiliki latar belakang ekonomi yang terbatas akan tetapi hal ini tidak menjadi hambatan bagi mereka dan hal ini membuat mereka yakin untuk maju dan tekun untuk belajar. Mereka sangat bersemangat untuk dapat melanjutkan studinya ke Perguruan Tinggi Negeri dan ke Akademi kedinasan. Mereka tidak merasa takut dan khawatir dengan kehidupan mereka yang terbatas. Siswa yang memiliki keyakinan yang tinggi menunjukkan adanya ketekunan dalam belajar serta tidak mudah putus asa ketika mendapat kegagalan dalam proses belajar.

Menurut Suminta (2014), siswa yang memiliki self efficaci yang tinggi menunjukkan adanya ketekunan dalam belajar serta tidak mudah putus asa ketika mendapat kegagalan dalam proses belajar. Self efficacy dapat membawa pada perilaku yang berbeda diantara individu dengan kemampuan yang sama karena self efficacy mempengaruhi pilihan, tujuan, penyelesaian masalah, dan kegigihan dalam berusaha. Self efficacy mampu mengatasi ketegangan dan kecemasan yang mengganggu yang berhubungan manipulasi angka dan pemecahan masalah matematika dalam berbagai kehidupan dan situasi akademis. Bandura (1997) menyatakan bahwa self efficacy terbagi atas dua yaitu self efficacy yang tinggi dan self efficacy rendah. Seseorag yang memiliki self efficacy tinggi dapat menurunkan rasa cemas akan kegagalan dan meningkatkan kemampuan kognitifnya, sehingga semakin tinggi self efficacy seseorang, maka semakin besar usaha yang akan dikeluarkan untuk menghadapi tantangan yang ada.

Suminta (2014) menyatakan faktor-faktor yang mempengaruhi kecemasan pada pelajaran matematika yaitu, dukungan keluarga, teman sebaya, guru dan self efficacy. Dukungan keluarga sangat bermanfaat dalam pengendalian seseorang terhadap tingkat kecemasan dan dapat pula mengurangi tekanan-tekanan yang ada dan konflik yang ada pada dirinya (Siregar \& Suryani, 2013; Isnainy \& Alfita. 2017; Fachrosi \& Sri, 2017; Afwina, 2019). Dukungan tersebut berupa dorongan, motivasi, empati, ataupun bantuan yang dapat membuat individu yang lainnya merasa lebih tenang dan aman. Dukungan didapatkan dari keluarga yang terdiri dari orangtua dan saudara kandung. Dukungan keluarga dapat mendatangkan rasa senang, rasa aman, rasa puas, rasa nyaman dan membuat orang yang bersangkutan merasa mendapat dukungan emosional yang akan mempengaruhi kesejahteraan jiwa manusia. Dukungan keluarga berkaitan dengan pembentukan keseimbangan mental (Rambe, 2017; Wati \& Cut, 2010; Sitanggang, \& Nini, 2014).

Manfaat dukungan keluarga menurut Cobb (dalam Gootlieb 1983) menyatakan setiap informasi apapun dari lingkungan sosial yang menimbulkan persepsi individu bahwa individu menerima efek positif, penegasan, atau bantuan menandakan suatu ungkapan adanya dukungan keluarga. Adanya perasaan didukung oleh lingkungan keluarga membuat segala sesuatu menjadi lebih mudah terutama pada waktu menghadapi peristiwa peristiwa yang menekan. Cobb menekankan orientasi subyektif yang memperlihatkan bahwa dukungan keluarga terdiri atas informasi yang menuntun orang, meyakini bahwa ia diurus dan disayangi.

Hasil observasi dan wawancara pada bulan Oktober 2016 dengan guru mata pelajaran matematika SMA Negeri 2 Sinabang sebagian besar mengalami kecemasan 
terhadap pelajaran matematika. Siswa kurang menyenangi kurang menyenangi pelajaran tersebut dan tidak ada keyakinan pada diri siswa untuk dapat menyelesaikan tugas-tugas yang diberikan guru. Selain itu siswa belum memahami kaitan pelajaran matematika dengan kehidupan sehari-hari sehingga banyak siswa yang memperoleh nilai matematika kurang memuaskan.

Sampai saat ini, kecemasan siswa pada pelajaran matematika belum dapat diatasi sepenuhnya, sejumlah usaha telah dilakukan untuk menyelesaikan permasalan kecemasan siswa pada pelajaran matematika ini. Sebagai contoh pihak sekolah dalam hal ini kepala sekolah membuat program yang meliputi : a). Dengan cara bertahap memberi materi dari yang paling mudah sampai pada materi yang sulit. b). Kursus diluar sekolah.

Program-program tersebut diatas adalah usaha penanggulangan dalam mengatasi kecemasan siswa yang selama ini telah dilaksanakan akan tetapi sejauh ini program tersebut belum menunjukkan tanda-tanda keberhasilan yang menggembirakan. Kurang berhasilnya program tersebut di atas salah satunya dapat dilihat dari sedikitnya jumlah siswa mendapat nilai 9 dan 8. Nilai yang mereka dapat hanya berada di angka 5 dan 6.

\section{METODE PENELITIAN}

Penelitian di lakukan pada siswa-siswi SMA Negeri 2 Sinabang. Penelitian ini dilaksanakan pada tanggal 3 Maret 2017. Populasi dalam penelitian ini adalah seluruh siswa siswi SMA Negeri 2 Sinabang yang berjumlah 120 orang. Sampel dalam penelitian berjumlah 60 siswa, yang diambil melalui teknik proporsional random sampling. Pengumpulan data pada peneltian ini menggunakan tiga skala dengan menggunakan skala Likert. Adapun tiga skala tersebut yaitu :

\section{Kecemasan siswa pada pelajaran matematika}

Kecemasan matematika akan diukur dengan menggunakan skala yang dikembangkan oleh Lestariningsih yang berdasarkan 2 aspek yaitu: berupa, Kehawatiran, ketegangan dan bingung. Sedangkan aspek fisiologis berupa keluar keringat dingin, gemetar, dan berdebar-debar. Setelah uji coba skala ini memiliki 28 item yang valid dan memiliki koefisien korelasi $r=0,310$ sampai $r=0,640$. Selanjutnya indeks reliabilitas Cronbachs Alpha memperoleh $\mathrm{rtt}_{\mathrm{t}^{\prime}}=0,916$ yang berarti skala ini reliabel.

\section{Self Efficacy}

Self efficacy dapat diukur melalui tiga aspek yang terkandung didalamnya, yaitu: magnitude (tingkat kesulitan tugas), 2.strength (kekuatan keyakinan) dan 3. Generality (generalitas). Setelah uji coba skala ini memiliki 27 item yang valid dan memiliki koefisien korelasi $r=0,302$ sampai $r=0,724$. Selanjutnya indeks reliabilitas Alpha memperoleh $r$ ' $=0,815$ yang berarti skala ini reliabel.

\section{Dukungan Keluarga}

Dukungan keluarga. Terdiri dari 2 aspek yaitu, dukungan emosional dan dukungan instrumental Setelah uji coba skala ini memiliki 27 item yang valid dan memiliki koefisien korelasi $r=0,311$ sampai $r=0,666$. Selanjutnya indeks reliabilitas Alpha memperoleh $r^{\prime}=0,816$ yang berarti skala ini reliabel. 


\section{HASIL DAN PEMBAHASAN}

\section{Uji Asumsi}

a. Uji Normalitas Sebaran

Uji normalitas sebaran dianalisis dengan menggunakan formula Kolmogorov_Smirnov Test. Berdasarkan analisis tersebut, maka diketahui bahwa data ke tiga variabel yang dianalisis mengikuti sebaran normal, yaitu berdistribusi sesuai. Sebagai kriterianya apabila $\mathrm{p}>0,050$ maka sebarannya dinyatakan normal, sebaliknya apabila $\mathrm{p}<$ 0,050 sebarannya dinyatakan tidak normal (Hadi dan Pamardingsih, 2000). Tabel berikut ini merupakan rangkuman hasil perhitungan uji normalitas sebaran:

Tabel 1. Hasil Uji Normalitas

\begin{tabular}{lccc}
\hline \multicolumn{1}{c}{ Variabel } & $\mathbf{Z}$ & $\mathbf{p}$ & Keterangan \\
\hline Kecemasan siswa pada pelajaran matematika & 1.451 & 0,030 & Sebaran normal \\
Self efficacy & 0.839 & 0.482 & Sebaran normal \\
Dukungan keluarga & 1.209 & 0.107 & Sebaran normal \\
\hline
\end{tabular}

b. Uji Linieritas Hubungan

Berdasarkan uji linieritas, dapat hasil analisis menunjukkan bahwa antara variabel bebas (self efficacy dan dukungan keluarga) mempunyai hubungan yang linier terhadap variabel terikat (kecemasan siswa pada pelajaran matematika). Sebagai kriterianya apabila $\mathrm{p}<0,050$ maka dinyatakan mempunyai derajat hubungan yang linier (Hadi dan Pamardiningsih, 2000).

Tabel.2. Hasil Uji Linieritas

\begin{tabular}{cccc}
\hline Variabel & F & p & Keterangan \\
\hline $\begin{array}{c}\text { Kecemasan siswa pada pelajaran } \\
\text { matematika dengan self efficacy }\end{array}$ & 5.534 & 0.025 & Linier \\
$\begin{array}{c}\text { Kecemasan siswa pada pelajaran } \\
\text { matematika dengan dukungan keluarga }\end{array}$ & 29.752 & 0.000 & Linier \\
\hline
\end{tabular}

\section{Hasil Perhitungan Analisis Regresi Berganda}

Berdasarkan hasil analisis yang menggunakan Analisis Regresi Berganda, diketahui bahwa terdapat kontribusi yang signifikan antara self efficacy (X1) dan dukungan keluarga (X2) dengan kecemasan siswa pada pelajaran matematika (Y). Hal ini ditunjukan dengan nilai koefisien $\mathrm{F}=12.239 ; \mathrm{R}=, 548 \mathrm{p}<0,000$. (Azwar, 1999). Berdasarkan kriteria tersebut maka diketahui bahwa hipotesis penelitian ini dinyatakan diterima, dengan kata lain bahwa terdapat hubungan negatif yang signifikan self efficacy dan dukungan keluarga dengan kecemasan siswa pada pelajaran matematika.

Tabel 3. Ringkasan Hasil Analisis Data

\begin{tabular}{ccccc}
\hline Variabel & F & r & r2 & p \\
\hline $\mathrm{X}_{1} \mathrm{Y}$ & - & -0.543 & 0.295 & 0.000 \\
$\mathrm{X}_{2} \mathrm{Y}$ & & -0.257 & 0.066 & 0.048 \\
$\mathrm{X}_{1} \mathrm{X} 2-\mathrm{Y}$ & 12.239 & -0.548 & 0.300 & 0.000 \\
\hline
\end{tabular}


Dari rangkuman tabel di atas diketahui koefisien korelasi antara rx1-y sebesar 0,543 dengan bobot sumbangan efektif sebesar $29.5 \%$ hal ini menunjukkan bahwa terdapat hubungan negatif yang signifikan antara self efficacy dengan kecemasan siswa pada pelajaran matematika. Kemudian diketahui koefisien korelasi antara rx2-y sebesar - 0,257 artinya adalah, terdapat hubungan negatif yang signifikan antara dukungan keluarga dengan kecemasan siswa pada pelajaran matematika, dengan bobot sumbangan efektif 6.6\%. Hal ini berarti self efficacy dan dukungan keluarga secara bersama-sama dapat digunakan sebagai prediktor untuk memprediksi kecemasan siswa pada pelajaran matematika.

\section{Hasil perhitungan Mean Hipotetik dan Mean Empirik}

Tabel 4. Hasil Perhitungan Nilai Rata-rata Hipotetik dan Nilai Rata-rata Empirik

\begin{tabular}{lcccc}
\multicolumn{1}{c}{ Variabel } & \multirow{2}{*}{ SD } & \multicolumn{2}{c}{ Mean/ Nilai Rata-rata } & \multirow{2}{*}{ Keterangan } \\
& & Hipotetik & Empirik & \\
\hline Kecemasan siswa pada matematika & 16,11 & 70 & 38.95 & Rendah \\
Self efficacy & 24.7 & 67.5 & 94.73 & Tinggi \\
Dukungan keluarga & 10.18 & 65 & 61.02 & Sedang \\
\hline
\end{tabular}

Berdasarkan perbandingan kedua nilai rata-rata di atas (mean hipotetik dan mean empirik), maka dapat dinyatakan bahwa subjek penelitian ini memiliki kecemasan siswa pada pelajaran matematika rendah, self efficacy yang tinggi dan dukungan keluarga yang sedang.

\section{SIMPULAN}

Berdasarkan hasil yang telah diperoleh dalam penelitian ini, maka dapat disimpulkan bahwa: terdapat hubungan negatif yang signifikan self efficacy dan dukungan keluarga dengan kecemasan siswa pada pelajaran matematika. Hal ini ditunjukan dengan koefisien $\mathrm{F}=12.239 ; \mathrm{rx} 12 \mathrm{y}=-0.548$ dan $\mathrm{p}<0,001$. Dengan demikian terbukti bahwa terdapat hubungan negatif yang signifikan antara variabel-variabel yang di teliti, semakin tinggi self efficacy dan dukungan keluarga, maka akan semakin rendah kecemasan siswa padapelajaran matematika. Oleh karena itu hipotesis yang diajukan dalam penelitian ini dinyatakan diterima. Ada hubungan negatif yang signifikan self efficacy dengan kecemasan siswa pada pelajaran matematika SMA Negeri 2 Sinabang. Diketahui berdasarkan koefisien korelasi $\mathrm{rx}_{1} \mathrm{y}=-0.543$; $<<0,001$; dan bobot sumbangan sebesar $29.5 \%$. Ada hubungan negatif yang signifikan dukungan keluarga dengan kecemasan siswa pada pelajaran matematika. Diketahui berdasarkan koefisien korelasi rx2y $=-0.257$; dan bobot sumbangan efektif yang didapatkan sebesar 6.6\%. Total sumbangan efektif dari kedua variabel bebas (self efficacy dan dukungan keluarga) dengan kecemasan siswa pada pelajaran matematika adalah sebesar 30\%. Dari hasil ini diketahui bahwa masih terdapat $70 \%$ sumbangan dari faktor lain terhadap kecemasan siswa pada pelajaran matematika.

Dari penelitian ini, diketahui bahwa yang memiliki self efficacy yang tergolong tinggi : berjumlah 60 orang, kategori sedang berjumlah 0 orang, tergolong rendah berjumlah 0 (tidak ada). Pada dukungan keluarga tergolong tinggi berjumlah 36 orang, tergolong sedang sedang 17 orang, rendah berjumlah 7 0rang. Pada kecemasan siswa pada pelajaran 
matematika yang tergolng tinggi berjumlah 58 orang, , tergolong sedang berjumlah 2 orang, tergolong rendah berjumlah 0 orang, dan tergolong rendah sekali berjumlah 0 (tidak ada).

\section{DAFTAR PUSTAKA}

Afwina, R. (2019). Kecerdasan Emosional, Dukungan Sosial, dan Stres Kerja Dokter Residen di Rumah Sakit Umum Pusat H. Adam Malik. Journal of Education, Humaniora and Social Sciences (JEHSS). 2 (2): 229236.

Amalia dan Metia, C. (2015). Pengaruh Tipe Kepribadian Diri Terhadap Kecemasan Siswa Dalam Menghadapi Ujian Nasional di SMA.Jurnal Consilium. Volume II, No. 2 Tahun 2015. Hal 1- 18.

Annisa Dwi K \& Siswono, T.Y.E., (2014). Pengaruh Kecemasan dan Self-efficacy Siswa Terhadap Kemampuan Pemecahan Masalah Materi Segi Empat Siswa Kelas VII MTs Negeri Ponorogo. MATHEdunesia. Jurnal Ilmiah Perndidikan Matematika. Vol. 3. No.2 Tahun 2014.

Bandura, A. (1997). Self-Efficacy: The Exercise of Control. New York: W. H. Freeman and Company.

Cohen, S. \& Syme, S.L, (1985). Social Support and Health. London Academic Press, Inc.

Fachrosi, E. \& Sri, S. (2017), Stress Akademik antara Siswa Pribumi dan Siswa Non pribumi di Sekolah Multikultural , Jurnal Diversita, 3 (1): 16-24.

Hadi, S. (2004). Metodelogi Research I. Yogyakarta: Andi offset.

Hurlock, E.B. 1997. Psikologi Perkembangan Suatu Pendekatan Sepanjang Rentang Kehidupan. Alih Bahasa : Istiwidayanti dan Soejarwo. Jakarta Erlangga.

Isnainy, A.A. \& Alfita, L. (2017). Perbedaan Coping Stress Penderita Kanker Ditinjau dari Jenis Kelamin di RSUP H. Adam Malik Medan, Jurnal Diversita, 3 (1): 1-9.

Kartono, K. (1981). Psikoilogi Abnormal \& Pathologi Seks: Penerbit Alumni, Bandung.

Nawangsari, N.A.F (2001) Pengaruh Self Efficacy dan Expectary Value Terhadap Kecemasan Mengahadapi Pelajaran Matematika. Psikologi Jurnal Pendidikan: Insan Media Psikologi.

Ormrod, J. E., (2003). Educational Psychologi: Developing Learners (4th Edition). Columbus, Ohio.

Rambe, Y. (2017). Hubungan Self Efficacy Dan Dukungan Sosial Dengan Kecemasan Siswa Menghadapi Ujian Nasional Berbasis Komputer (UNBK) Di SMK Swasta PAB 12 Saentis. Analitika: Jurnal Magister Psikologi UMA, 9(1), 60-67. doi:https://doi.org/10.31289/analitika.v9i1.740

Rifai, M. E., (2014). Hubungan Kepercayaan Diri Dan Dukungan Keluarga Dengan Kecemasan Matematika. Naskah Publikasi. Universitas Muhammadiah: Surakarta.

Rosadah, M., \& Budiarto, M.T., (2013). Profil Siswa Dalam Memecahkan Masalah Matematika Diiringi Musik Ditinjau Dari Tingkat Kecemasan dan kemampuan Matematika Siswa. MATHEdunesa. Vol. 2. No.1 Tahun 2013.

Ruseffendy. (1990). Pengantar Matematika Modern Bandung: Tarsito

Sarason, I. G, Levine, H.M. Masham, R.B and Sarason, B.R, (1983), Assesing Social Support: The Social Support Questionnaire. Jurnal of personality and Social Psycology 44.

Schunk, D. H. (1991). Self-efficacy and academic motivation. Educational Psychocogy 26, 207-231.

Siregar, I.M., Suryani H., (2013), Hubungan Kecemasan Kematian dan Dukungan Sosial Terhadap Motivasi Kerja Karyawan ODHA (Orang Dengan Hiv-Aids), Analitika: 5 (2): 26-32

Sitanggang, O.E.Y., Nini S.W., (2014), Hubungan antara Efikasi Diri dengan Kecemasan pada Calon TKI, Analitika: 6 (1): 37-43

Solikah, M. (2012). Pengeruh Kecemasan siswa Pada Matematika Dan Motivasi Belajar Terhadap Prestasi Belajar Matematika. Naskah Publikasi. Universitas Negeri Surabaya.

Sugiono, (2013). Penelitian Kuantitatif, Kualitatif R \& D. Bandung: Alfabeta

Suminta, R. R.. (2014). Faktor-Faktor Yang Mempengaruhi Kecemasan Matematika Pada Siswa SMA. Disertasi. Program Doktor Psikologi. Universitas Gajah Mada: Yogyakarta.

Syawahid, M. (2011). Kecemasan Matematika Dan Cara Menguranginya. Jurnal Psikologi. Universitas Negeri Yogyakarta.

Wati S, P., Cut M., (2010), Hubungan antara Dukungan Sosial Keluarga dan Self Efficacy dengan Kemandirian Belajar pada Siswa SMKN 2 Medan, Analitika: 2 (2): 45-54

Wentzel, K. R, \& Wigfied, A., (2009). Handbook of Motivation at School, New York, London. Routletge.

Wiramihardja, S. A, (2015). Pengantar Psikologi Abnormal. Bandung, PT Refika Aditama. 